УДК 821.161.2-3

DOI 10.31.65/2520-6966-2020-14f-98-57-65

А. В. Колесник

кандидат фрілологічних наук, завідувач кафедри українознавства та іноземних мов

Дніпропетровського державного університету внутрішніх справ

ORCID: 0000-0001-7812-0035, e-mail: coalision@ukr.net

\title{
Натуралістичне зображення постатей євреїв у новелі Івана Франка "На дні" як віддзеркалення соціальної дійсності Галичини XIX століття
}

У статті аналізуються особливості художнього зображення євреїв у новелі I. Франка "На дні", визначаються елементи натуралізму у відтворенні персонажів і соціальної дійсності. Автор статmі спирається на думку провідних науковців щодо проблеми натуралізму в українській літературі, зокрема про дотримання Іваном Франком у своїй ранній творчості програмових вимог натуралізму.

В основі дослідження - визначення типологічних характеристик зображення євреїв у новелі І. Франка "На дні" відповідно до основоположних домінант натуралізму, зокрема, точного, майже наукового відображення усіх явищ в житті, об'єктивності, поєднання у художньому зображенні природних і соціальних складових, фрактографрічності. У статmі аналізується виявлення цих ознак у зображенні двох постатей євреїв: старого, чесного робітника з Борислава і молодого парубка - міського злодія.

Визначено, що життєподібність виявляється в описі зовнішніх ознак, які характеризують матеріальний стан персонажів: виснажених рис обличчя старого єврея, який працював у Бориславі, та одягу хлопия-єврея, що свідчить про його злидні, а також у натуралістичному описі тюремної камери та ї мешканців у цілому. Узагальнення і типізація виявляються у позбавленні персонажів індивідуальності - відсутність імен в обох євреїв, стирання національних ознак, зокрема мовних у хлопця-єврея, що використано для введення його в категорію "свій" в українському суспільстві Галичини. Фактографізм спостерігаємо в описі вирваних з потоку життя кадрів, "шматків": моментів сну героїв - з метою створення уявлення про їхнє важке життя; в описі жахливих картин, зокрема кривавої бійки в тюремній камері, що створені з метою змусити читача замислитись $i$ змінити своє ставлення до соціальних проблем суспільства.

У статmі зроблено висновок, що за допомогою натуралістичного зображення письменник відтворив у новелі тип більшості євреїв того часу, які змушені були виживати будь-яким способом і мали такі ж самі соціальні проблеми, як і більшість українців Галичини, що віддзеркалює намагання письменника змінити суспільство.

Ключові слова: натуралізм, І. Франко, новела "На дні", образи євреїв, життєподібність, фрактографрізм, соціальна дійсність, Галичина. 
Постановка проблеми. Проблема натуралізму в українській літературі розглядалася неодноразово з різнополярними висновками про наявність або відсутність у ній цього літературного напряму. Науковці однозначні у висновку про те, що Іван Франко у своїй ранній творчості свідомо дотримувався програмових вимог натуралізму і був представником цього літературного напряму. Не є винятком і зображення євреїв у художній прозі І. Франка. Аналіз натуралістичної складової дозволить з'ясувати мету її використання письменником при створенні образів євреїв.

Аналіз публікацій. Натуралізм в українській літературі як творчий метод та стильовий напрям досліджували Д. Наливайко [1], В. Поважна [2]. Проблемі натуралізму у творчості І. Франка, зокрема питанням відповідності творчого методу письменника натуралізму, свідомого дотримання І. Франком вимог напряму, порівняльним аспектам національних виявів натуралізму присвячені роботи Т. Денисової [3], Т. Гундорової [4], Р. Голода [5; 6], М. Ткачука [7], Н. Венгринович [8] та інших. Єврейську тематику в художній прозі І. Франка досліджено автором статті [9]. Водночас особливості художнього зображення євреїв у прозі І. Франка в контексті відповідності стильовим ознакам натуралізму залишаються не дослідженими.

Метою статті $€$ визначення, відповідно до основоположних домінант натуралізму, типологічних характеристик зображення євреїв у новелі І. Франка "На дні", що $€$ віддзеркаленням соціальної дійсності Галичини XIX століття.

Виклад основного матеріалу. Д. Наливайко визначив чотири ознаки натуралізму як стильового напряму. Серед них - точне відображення усіх явищ в житті, що перетворює письменника в науковця, який досягає своєї мети завдяки спостереженню і ретельному, майже науковому вивченню явищ; об'єктивність, що виявляється у відтворенні подій без вияву авторської присутності; поєднання у художньому зображенні природних (біологічних, фрізіологічних) і соціальних складових; правдивість зображення відповідно до життя, на підставі чого виникає фрактографрічність [1, с. 120].

Під впливом ідей позитивізму натуралісти надавали пріоритет зображенню очевидних фрактів і явищ, шукаючи їхні безпосередні причини в навколишньому середовищі. Тому основна увага митців була сконцентрована на соціальній дійсності, що і була причиною явищ та обставин у житті героїв. Засновник натуралістичного напряму Е. Золя відзначав, що для натуралістів дійсні фракти, дійсність $€$ непохитною основою. Але щоб показати механізм фрактів, потрібно викликати і спрямовувати явища, а для цього митцям необхідна творча франтазія [6, с. 247]. 
В українській літературі принципи натуралізму, сформовані Е. Золя, найсуттєвіше виявилися у творчості Івана Франка, який у ранній період творчості (1980-1990 рр.) дотримувався цього напряму з метою пошуку способів зміни суспільства, що відображено у його публіцистичних творах.

У новелі "На дні" І. Франко, використовуючи прийоми натуралізму, висвітлив проблему несправедливого ув'язнення людей у провінційних містечках Галичини другої половини XIX століття. Причиною цього становища була соціальна ситуація в суспільстві, а саме те, що незабезпечені прошарки населення були в повній залежності від капіталістів, які на той час володіли усіма засобами виробництва. 3 цього приводу І. Франко зазначає у статті "Про працю", що насправді робітники були простими наймитами, настільки залежними від капіталіста, що за суспільним становищем нагадували новий вид рабів: "Оце і $є$ нинішній робітник - справжній раб капіталу, білий негр" [10, с. 67]. А 3 огляду на те, що заможними капіталістами був незначний відсоток населення, то у становищі "рабів" перебувало майже все населення Галичини.

Новела "На дні" створена письменником під час ув'язнення в Коломиї у 1880 р. У ній змальовано трагічну долю русина-інтелігента Андрія Темери, який несправедливо потрапив до тюрми через відсутність документів, а також становище ще вісьмох арештантів чесних робітників з Борислава, які через збіг обставин опинилися за ґратами, та справжніх злочинців.

Розповідач вдається до опису долі кожного мешканця камери. Серед них - два євреї: старий, чесний робітник з Борислава і молодий парубок - міський злодюжка. Ці персонажі $є$ другорядними, у них навіть немає імен, на відміну від персонажів-українців, що позбавляє їх індивідуальності і надає їм фрункції узагальнення стереотипного уявлення про євреїв того часу.

Читача вражає життєподібність опису в новелі, де в усіх деталях показано середовище тюремної камери, передано важку психологічну атмосфреру та стан кожного ув'язненого. У свій час новела "На дні" своїм новаторством привернула увагу української, польської і єврейської молоді [5, с. 153]. I хоч у цілому твір є психологічно важким викриттям "високої школи дна суспільства" [11, с. 493], все ж письменник намагався показати позитивні риси кожної жертви цієї "школи".

Вже перший опис єврея позначений натуралістичним відтворенням, у якому переважає фрактографічність: "...коло самих дверей лежав старий жид з безмірно сухим та нужденним лицем, сухими, мов граблі, руками і з космами сивого волосся на бороді" [11, с. 115]. 
Зовнішність персонажа насичена ознаками, які свідчать про важке життя цієї людини, безперестанну роботу, нестачу харчування, що і стали причиною зображеного фрізичного стану персонажа.

Опис того, як саме лежав єврей, також відтворює соціальні умови, в яких звикла перебувати ця людина: "Його голова, коротко обстрижена, спочивала, важко звішена, на мокрій плиті, а на довгій тонкій шиї понадувалися жили, мов понатягане мотуззя. Він спав твердо з роззявленим безуббим ротом, харкотів, мов підрізаний, а з рота спливала по бороді слина" [11, с. 115]. Спостереження за моментом сну, зображене як "скопійований шматок життя", наводить на думку, що ця людина звикла користуватися будь-якою хвилиною, аби заснути і відновити свої сили, чим узагальнює в уявленні читача причини надмірного виснаження чоловіка. Простежуємо фрактографрізм опису в цьому епізоді з фріксуванням усіх деталей страшного вигляду єврея під час сну, що, своєю чергою, підсилює соціальний мотив у поясненні причин такого стану. Таким чином натуралістичні засоби несуть смислове навантаження.

Проте в цілому зображення старого єврея набуває позитивного забарвлення завдяки виявленому доброзичливому ставленню головного оповідача у камері - діда Панька, колишнього солдата, інваліда, який розповідає, що цей єврей "тяг, неборачисько, зо мною корбу в Бориславі довгі роки" [11, с. 118], що одразу створює уявлення про старого як чесну, працьовиту людину. Характеристика єврея, висловлена дідом Паньком, з означеннями "щира душа" та "золоте серце" виявляє співчуття оповідача і дружнє ставлення до цієї постаті.

Старий єврей "зріс межи нашими людьми, бідував, працював сам від малу так, як наш чоловік" [11, с. 118]. Таке життя і ставлення до важкої праці переводять єврея з категорій "чужий", "інший" до категорії "свій". У нього добре серце, він "щоби сам не знати в якій біді, то ніколи не буде перед другими розводити своїх жалів, а вже другого пожалує й поможе чим може, так як і рідний брат" [11, c. 118]. I тільки елементи зовнішності залишають його "іншим": "якби не та борода, не пейси та не тота бекеша, то по єго натурі ніхто би не сказав, що то жид!" [11, с. 118].

Згодом розповідач повертає читача до теперішніх подій у камері, відновлюючи тяжке враження про цього чоловіка, яке повторюється у сприйнятті Темери і відтворено фрактографічно, за допомогою зовнішніх елементів і порівняння обличчя зі штучним дерев'яним каркасом: "нужденне сухе лице, що здавалося немов зроблене з патичків і обтягнене бурим поморщеним саф'яном ... тяжке хрипіння в груді віщувало, що сьому чоловікові недовго вже жити на світі, а вся його 
постать аж надто голосно говорила, що й минуле його життя було не життя, а вічне нидіння та бідування" [11, с. 118]. За допомогою цього опису розповідач ніби розшифровує, для чого він вдався до непривабливого зображення зовнішніх рис старого - для того, щоб показати як впливають соціальні чинники на людину.

Зі ще одним персонажем-євреєм читач знайомиться у другому розділі оповідання. Вже при першій згадці розповідач знов вдається до опису пози, в якій лежав хлопець під час сну, порівнюючи його 3 собакою, що наштовхує на думку про нужденне життя, яке вимагає вміння пристосовуватися до обставин, як це роблять тварини: "При ногах діда, скулившися вдвоє, мов песик, лежав невеликий чорноволосий хлопчик в чорних міських штанях, в брудній сорочці зо склепового тонкого полотна, немилосердно пофалатаній на всі боки..." [11, с. 114]. Н. Венгринович зауважує, що натуралісти, спираючись на теорію Ч. Дарвіна, були переконані, що людина - та сама тварина і всі її вчинки спровоковані фізіологічними чинниками [8, с. 113].

Детальна фіксація дрібниць, зокрема стану одягу хлопця, відбиває ретельне спостереження за моментом сну, "копіювання" цієї миттєвості з реального життя. Такі означення сорочки, як "брудна", "пофралатана", а полотна - "склепове", "тонке", передають скрутне фрінансове становище юнака і відсутність будь-якої можливості задовольнити потребу в одязі, а разом із характеристикою "кішіньковний майстер" пояснюють причину перебування хлопця у камері його соціальним становищем, в якому простежується матеріальна незабезпеченість. Коли хлопець знайшов гроші у камері, то втішася неймовірно, незважаючи на дрібну суму - чотири крейцари, і "рад би був накупити бог зна яких достатків, щоб провести празнично нинішній щасливий день" [11, с. 142], що підтверджує припущення про злидні юнака.

I так само як старий єврей, хлопчина спав дуже міцно "... і не прокинувся навіть від стуку дверей" [11, с. 114]. Звернемо увагу, що в обох персонажів зафріксований момент сну, як са́ме він відбувається: міцний, безпробудний сон, по дитячому спокійний, безтурботний, як єдина можливість втекти від страшної соціальної дійсності, що їх оточує. Проте автор уникає опису обличчя юнака, на відміну від опису старого єврея: "Лиця його не міг Андрій доглянути, бо він спав твердо..." [11, с. 114], що підкреслює узагальнюючу функцію персонажа, роблячи його представником ряду пересічних євреїв, які виживали будь-яким способом, у тому числі дрібною крадіжкою та обманом. Саме цим займався хлопчина - "кішінковий майстер..." [11, с. 123], за визначенням діда Панька. Й інший мешканець камери, 
селянин з села Дрожів, опинився у камері через обман, вчинений євреєм: "десь, у якогось жидика, купив шкіру за 30 крейцарів, а шкіра вартувала з півтора ринського. То жидик 30 кр[ейцарів] у руки та втеки, а його, наймита божого, жиди в руки та до Іванової хати!.." [11, с. 130].

Ставлення урядовців і жандармів до євреїв позначено байдужістю, як, утім, і до інших ув'язнених. Дід Панько з'ясовує, що хлопець сидить у камері вже два тижні і його жодного разу не викликали на допит, що дуже вражає Темеру як головного свідка подій i нейтрального спостерігача: "Ані разу не кликали - за дві неділі?! скрикнув Андрій". I відповідь діда Панька відображає реальний стан справ у системі судочинства Галичини того часу: "таки що не кликали. Сидить та й сидить, і пес за ним не гавкне, а пану інспекторові не квапно ся діє..." [11, с. 123], - змушуючи читача замислитись над тим, що треба не лише спостерігати, а щось робити. На думку Р. Голода, і Е. Золя, й І. Франко бачили своїм завданням дати людям "дзеркало" чи "фотографії", в яких би відбивався реальний стан речей, щоб, побачивши правдиве життя, люди могли зробити відповідні висновки і згодом змінити його на краще [5, с. 104].

Та й ставлення до євреїв, очевидно, виклика́ло занепокоєння письменника, який перемежовує розповідь про перебування Темери у камері коротким описом того, що він чув знадвору - сміх і суперечки "поліціянів", які безтурботно грали у "кікса", скрип криниці, а ще "крик якихось жидів, переймлених на дорозі враз із стадом волів та загнаних на комунальне подвір'я" [11, с. 130]. Усі ці вихоплені з дійсності слухові спостереження створювали враження "понурого сумерку" й безвиході [11, с. 130].

Важке соціальне становище відображено в діалозі хлопця з Бовдуром, ще одним мешканцем камери, який перебуває в ув'язнені більше ніж пів року. У розмові йдеться про бажання з"їсти шмат хліба, а згодом це стає причиною кривавої бійки. Бовдур зображений у надмірно натуралістичних тонах, є дзеркалом повної деградації людини під впливом соціальних обставин, "змалюванням патологічного типу..., чия поведінка значною мірою зумовлена фізіологічними чинниками" [5, с. 152].

Діалог супроводжується відтворенням відповідного психічного стану персонажів, який фіксується у мові. При цьому у мові юнака спостерігаємо розмовні елементи саме української мови: "Вступися по добру́ та хирій, бо я їсти хочу" або "Чи ти стікся, чи що?", "іди собі з богом до дідька" [11, с. 130], що стирає національні ознаки єврея і 
робить його одним із членів українського суспільства, переводячи до категорії "свій".

Символічного змісту набуває образ хліба під час бійки хлопцяєврея з Бовдуром, особливо у той момент, коли після удару "повалився жидик додолу, а кров з носа і з рота булькнула і полилася на хліб..." [11, с. 146], в якому поєднуються незіставні з погляду пересічного читача елементи: святий хліб і кров, пролита силою. Тим самим письменник створює ефект несподіваного враження у читача, намагаючись змусити його зробити висновок, що за будь-яких умов необхідно залишатися "людиною", протидіяти насильству.

Висновки. Отже, в оповіданні "На дні" зображено узагальнені типи євреїв, описи яких відповідають основним принципам натуралізму: життєподібності, узагальнення і типізації, фрактографрізму.

Життєподібність виявляється в описі зовнішніх ознак, які характеризують матеріальний стан персонажів, зокрема виснаженого обличчя й тіла старого єврея, який важко працював у Бориславі, одягу хлопця-єврея, що свідчить про його злидні, а також у натуралістичному описі тюремної камери та їі мешканців у цілому. Узагальнення і типізація виявляються у позбавленні персонажів індивідуальності відсутність імен в обох персонажів-євреїв, що надає їм узагальнюючої функції. Водночас у творі наявна індивідуалізація мови, зокрема хлопця-єврея, що використана для наближення його до категорії "свій". Фактографізм спостерігаємо в описі вирваних з потоку життя кадрів: моментів сну героїв у тюремній камері - 3 метою узагальнення уявлення про їхнє важке життя. Також фрактографрізм наявний в жахливих картинах, зокрема у сцені кривавої бійки персонажів, що створена з метою змусити читача замислитись над умовами життя і змінити своє ставлення до проблем суспільства.

За допомогою натуралістичного зображення письменник відтворив тип більшості євреїв Галичини того часу, які змушені були виживати будь-яким способом. І. Франко узагальнив думку про те, що євреї мали такі ж самі соціальні труднощі, як і більшість українців Галичини, використав натуралістичні прийоми зображення для розкриття власної громадянської гуманістичної позиції: він проти приниження людини, безправного існування та нерівності, спричинених матеріальними або національними ознаками.

Подальший аналіз натуралістичних аспектів зображення дійсності та постатей євреїв у прозі І. Франка дозволить з'ясувати значення та мету звернення письменника до натуралізму в художній прозі та визначити вектори досліджень натуралістичного напряму в українській літературі. 


\section{Література}

1. Наливайко Д. Проблема натуралізму в українській літературі. Літературознавство: матеріали III конгресу Міжнародної асоціації україністів. Київ, 1996. С. 118-130.

2. Поважна В. Розвиток української літературної критики у 80-90-х роках XX ст. (До проблеми критеріїв і методу). Київ, 1973. 268 с.

3. Денисова Т. Н. Иван Франко и натурализм. Іван Франко і світова культура: матеріали міжнародного симпозіуму ЮНЕСКО (Львів, 11-15 вересня 1986 р.). Київ: Наукова думка, 1990. Кн. 1. С. 229-231.

4. Гундорова Т. Франко не Каменяр. Франко і Каменяр. Київ: Критика, 2006. $352 \mathrm{c}$.

5. Голод Р. Іван Франко та літературні напрями кінця XIX - початку XX століття. Івано-Франківськ: Лілея-НВ, 2005. 288 с.

6. Голод Р. Натуралізм. Дивослово. 2012. № 4. С. 50-56.

7. Ткачук М. П. Жанрова структура прози Івана Франка (бориславський цикл та романи з життя інтелігенції): монографічне дослідження. Тернопіль, 2003. $384 \mathrm{c}$.

8. Венгринович Н. Р. Зооморфнна образність у натуралістичній прозі Івана Франка та Френка Норріса. Науковий вісник Міжнародного гуманітарного університету. Серія "Філологія". Одеса. 2017. № 27. Т. 1. С. 112-115.

9. Колесник А. В. Єврейська тематика в художній прозі Івана Франка: автореф. дис. ... канд. фрілол. наук: 10.01.01. Київ, 2016. 24 с.

10. Франко І. Зібрання творів: у 50 т. Київ: Наукова думка, 1976-1986. Т. 44. Кн. 1: економічні праці (1878-1887). 695 с.

11. Франко І. Зібрання творів: у 50 т. Київ: Наукова думка, 1976-1986. Т. 15. Повісті та оповідання (1978-1982). 511 с.

\section{References}

1. Nalyvayko D. (1996). Problema naturalizmu v ukrayins'kiy literaturi [The Problem of Naturalism in Ukrainian Literature]. Literaturoznavstvo: Materialy III konhresu Mizhnarodnoyi asotsiatsiyi ukrayinistiv - Literary Studies: Proceedings of the Third Congress of the International Ukrainian Association. Kyiv. 118-130 [in Ukrainian].

2. Povazhna V. (1973). Rozvytok ukrayins'koyi literaturnoyi krytyky u 8090-kh rokakh KHKH st. (Do problemy kryteriyiv i metodu) [The development of Ukrainian literary criticism in the 80-90-ies of XX century. (To the problem of criteria and method)]. Kyiv [in Ukrainian].

3. Denysova T. N., (1990) Yvan Franko y naturalyzm [lvan Franko and naturalism]. Ivan Franko i svitova kul'tura. Materialy mizhnarodnoho sympoziumu YUNESKO (L'viv, 11 - 15 veresnya 1986) - Ivan Franko and the World Culture. Proceedings of the UNESCO International Symposium (Lviv, 11-15 September 1986). Kyiv: Naukova dumka, Book. 1. 229-231 [in Ukrainian].

4. Hundorova T. (2006). Franko ne Kamenyar. Franko i Kamenyar [Franco not Stonecutter. Franco and the Stonecutter]. Kyiv: Krytyka [in Ukrainian].

5. Holod R. (2005). Ivan Franko ta literaturni napryamy kintsya XIX pochatku XX stolittya [Ivan Franko and the literary trends of the late XIX - early XX centuries]. Ivano-Frankivs'k: Lileya-NV [in Ukrainian].

6. Holod R. (2012). Naturalizm [Naturalism]. Dyvoslovo - Wonder word. № 4. 50-56 [in Ukrainian]. 
7. Tkachuk M. P. (2003). Zhanrova struktura prozy Ivana Franka (boryslavs'kyy tsykl ta romany $z$ zhyttya intelihentsiyi) [The genre structure of Ivan Franko prose (the Borislav cycle and novels from the life of the intellectuals)]. Ternopil' [in Ukrainian].

8. Venhrynovych N. R. (2017). Zoomorfna obraznist' u naturalistychniy prozi Ivana Franka ta Frenka Norrisa [Zoomorphic imagery in the naturalistic prose of Ivan Franko and Frank Norris]. Naukovyy visnyk Mizhnarodnoho humanitarnoho universytetu. Seriya: Filolohiya [Scientific Bulletin of the International Humanities University. Series: Philology]. Odessa. № 27. Vol. 1. 112-115 [in Ukrainian].

9. Kolesnyk A. V. (2016). Yevreys'ka tematyka v khudozhniy prozi Ivana Franka [Jewish topics in Ivan Franko's prose]. Kyiv [in Ukrainian].

10. Franko I., (1976-1986). Zibrannya tvoriv: u $50 t$. [Collection of works: in 50 vol.]. Ekonomichni pratsi (1878 - 1887) [Economic works (1878-1887)]. (Vols. 1-50; Vol. 44; Book 1) Kyiv: Naukova dumka [in Ukrainian].

11. Franko I., (1976-1986). Zibrannya tvoriv: u 50 t. [Collection of works: in 50 vol.]. Povisti ta opovidannya (1978 - 1982) [Tales and Stories (1978-1982)] (Vols. 1-50; Vol. 15) Kyiv: Naukova dumka [in Ukrainian].

\section{Alla Kolesnyk \\ Doctor of Philosophy (PhD), Head of the Department of Ukraine-study and Foreign Languages of Dnipropetrovsk State University of Internal Affairs}

\section{The naturalistic image of jews in I. Franko's novel "At the bottom"}

In the article the peculiarities of the artistic image of the Jews in the novel by I. Franko "At the bottom" are analyzed, the elements of naturalism in the reproduction of the images of Jews are identified.

The author of the article draw on the opinion of leading scholars on the problem of naturalism in Ukrainian literature, in particular, on the adherence of Ivan Franko in his early work to the program requirements of naturalism.

The research is based on the determine of the typological characteristics of the image of the Jews in the novel by I. Franko "At the bottom" in accordance with the fundamental dominants of naturalism, in particular, the accurate, almost scientific reflection of all phenomena in life, objectivity, combination in the artistic depiction of natural and social components, factuality. The manifestation of these features in the depiction of two figures of Jews: an old, honest worker from Borislav and a young man - a city thief are analyzed in the article.

It is determined that the vitality is manifested in the description of the external signs that characterize the material state of the characters: the exhausted features of the face of an old Jew who worked in Boryslav, and the clothing of a Jewish boy, which reveal his poverty, as well as in the naturalistic description of the prison cell and prisoners as a whole. Generalizations and typing are manifested in the deprivation of characters of individuality - the absence of names of both Jews, the deprivation of national features, in particular, the language features of a Jewish boy, which was used to introduce him into the category of one of the members of Ukrainian society of Galicia. Factography is observed in the description of frames taken from the flow of life, "pieces": moments of the heroes' dream - in order to create an idea of their difficult life; in depicting horrific paintings, including a bloody jailbreak, designed to get the reader to think and change their attitude to the social problems of society.

The article concludes that with the help of a naturalistic image the writer recreated the type of majority of Jews of that time who were forced to survive in any way and had the same social problems as most Ukrainians of Galicia, reflecting the writer's attempt to change society.

Key words: naturalism, I. Franko, novel "At the bottom", the images of Jews, vitality, factography, social reality, Halychyna. 